\title{
Assessment of a system for the prediction of water permeability coefficient in pervious concretes
}

\section{(Avaliação de um sistema para a predição do coeficiente de permeabilidade de água em concretos permeáveis)}

\author{
A. Ribeiro ${ }^{1}$, V. dos Santos ${ }^{1 *}$ D. T. Pagnussat ${ }^{2}$, R. N. Brandalise ${ }^{1}$ \\ ${ }^{1}$ Universidade de Caxias do Sul, Centro de Ciências Exatas e da Tecnologia, R. Francisco Getúlio Vargas 1130, \\ 95070-560, Caxias do Sul, RS, Brazil \\ ${ }^{2}$ Universidade Federal do Rio Grande do Sul, Departamento Interdisciplinar do Campus Litoral Norte, \\ Tramandai, RS, Brazil
}

\begin{abstract}
Proposing a system which makes it possible to determine the water permeability coefficient in pervious concretes in a practical way, without the need of devices which require complex instrumentation, is one of the aims of this work. An experimental matrix was proposed for the evaluation of the measurement system of the coefficient of permeability into pervious concrete considering three different pervious concretes obtained from different aggregate granulometric sizes, under the condition of dry sample or water saturated. The pervious concretes were characterized by their void contents, mechanical properties and later compared with the properties of a reference, control concrete made up of coarse and fine aggregates. The different properties exhibited in this study were assessed aiming at validating the experimental matrix developed for pervious concretes to provide a basis for comparison with information available in the literature. As a noticeable result, it was evidenced that the permeability coefficient of $0.21 \mathrm{~cm} . \mathrm{s}^{-1}$ obtained for concrete with aggregate dimensions of 2.4 to $9.5 \mathrm{~mm}$. It is possible to measure the coefficient of permeability of pervious concrete with the system developed in this study; the obtained results agree with the description of ACI52206 for pervious concretes.
\end{abstract}

Keywords: pervious concrete, properties, measurement system, coefficient of permeability.

\section{Resumo}

A proposta de um sistema que possibilita a determinação do coeficiente de permeabilidade à água em concretos permeáveis de forma prática, sem a necessidade de dispositivos que requeiram instrumentação complexa, é um dos objetivos deste trabalho. Uma matriz experimental foi proposta para a avaliação do sistema de medição do coeficiente de permeabilidade em concretos permeáveis considerando três concretos permeáveis diferentes, obtidos a partir de diferentes tamanhos granulométricos de agregados, sob condição de amostra seca e saturada de água. Os concretos permeáveis foram caracterizados por índice de vazios e propriedades mecânicas, tendo posteriormente suas propriedades comparadas às de um concreto referência, composto por agregados graúdos e miúdos. As diferentes propriedades neste estudo foram determinadas visando validar a matriz experimental desenvolvida para concretos permeáveis e propondo fornecer uma base de comparação com as informações disponíveis na literatura. Como resultado, evidenciou-se que o coeficiente de permeabilidade de $0,21 \mathrm{~cm} \cdot \mathrm{s}^{-1}$ foi obtido para o concreto com dimensões de agregados de 2,4 a 9,5 $\mathrm{mm}$. É possível medir o coeficiente de permeabilidade do concreto permeável com o sistema desenvolvido neste estudo, sendo que os resultados obtidos estão em acordo com a descrição do ACI522-06 para concretos permeáveis.

Palavras-chave: concreto permeável, propriedades, sistema de medida, coeficiente de permeabilidade.

\section{INTRODUCTION}

Pervious concrete is a type of concrete with a high degree of interconnected voids prepared with little or no fine aggregate, which permits unobstructed passage of large amounts of water [1]. For preparing such concrete the water and cement amounts are controlled and for most of the mixes water, cement and coarse aggregate are employed, leading to applications for the control of the surface runoff of rainwater, restoration of ground waters, making it even 
possible in certain cases to filtrate pollution [1,2]. Generally speaking, the density of pervious concrete is in the range of 1600 to $2000 \mathrm{~kg} . \mathrm{m}^{-3}$; it can be prepared on-site, based on local materials, avoiding high transportation costs [3]. According to the American Concrete Institute (ACI) 522R [3], pervious concrete mixtures may exhibit compressive strength ranging from 3.5 to $28 \mathrm{MPa}$, after 3 to 28 days, and a void content of 15 to $25 \%$. The splitting tensile strength in pervious concrete generally ranges between 1.0 and $3.8 \mathrm{MPa}$ [4]. According to the literature $[3,5-8]$, the permeability coefficient can take different values $\left(0.01\right.$ to $0.1 \mathrm{~cm} . \mathrm{s}^{-1}$ [5], 0.02 to $0.06 \mathrm{~cm} . \mathrm{s}^{-1}$ [6], $0.14 \mathrm{~cm} . \mathrm{s}^{-1}$ [3], and 0.2 to $0.54 \mathrm{~cm} . \mathrm{s}^{-1}$ $[7,8])$. The different results of the various studies are based on: kind of aggregate, granulometric curves, dosage, cement, void index, etc. reported by ACI [3]. The document reports a minimum value of $0.14 \mathrm{~cm} . \mathrm{s}^{-1}\left(1.40 \times 10^{-3} \mathrm{~m} . \mathrm{s}^{-1}\right)$ for the permeability coefficient [3]. The permeability of pervious concretes is dependent on the structure of their pores.

Hydraulic conductivity is a quantitative measurement, which characterizes the flow of water through the porous media. Permeability is an important parameter in the mathematical modeling of the groundwater flow simulation, derived from Darcy's law for porous media; it allows the characterization of water flow. This property varies with the water content in the porous medium and is generally considered a function of the saturation degree of media or water absorption by the concrete matrix $[3,9]$. The literature reports methods based on Darcy's law for measuring the hydraulic conductivity of a porous material under a saturated water condition; however, studies by several authors $[5,7$, $10,11]$ mention that the saturation of the porous sample is due to the initial exposure. There are two distinct types of equipment used for measuring the water permeability coefficient: a constant load equipment and a variable load equipment. A constant load equipment determines the water permeability coefficient by measuring at a constant flow rate the amount of water crossing the sample at a certain fixed reading period [12-14]. In this kind of permeameter, Eq. A is used for the calculation of the permeability coefficient. On the other hand, the variable load permeameter assesses the water permeability coefficient by measuring the water volume reduction (which at first is fixed) crossing the concrete sample during the percolation period $[1,5,7,9$, $15,16]$. For this kind of permeameter, Eq. B is used for the calculation of the permeability coefficient.

$$
\mathrm{k}=\frac{\mathrm{QL}}{\mathrm{HAt}}
$$

where $\mathrm{k}$ is the water permeability coefficient in $\mathrm{cm} . \mathrm{s}^{-1}$, $\mathrm{Q}$ is the amount of water collected in $\mathrm{cm}^{3}$ throughout time $\mathrm{t}$ in $\mathrm{s}$, $\mathrm{L}$ is the sample length in $\mathrm{cm}, \mathrm{H}$ is the difference between the level of the upper $\left(h_{2}\right)$ and the lower $\left(h_{1}\right)$ water column in $\mathrm{cm}$, and A the sample cross-section area in $\mathrm{cm}^{2}$.

$$
\mathrm{k}=\frac{\mathrm{aL}}{\mathrm{At}} \ln \frac{\mathrm{h}_{1}}{\mathrm{~h}_{2}}
$$

where: $\mathrm{k}$ is the coefficient of water permeability in $\mathrm{cm} \cdot \mathrm{s}^{-1}$, $\mathrm{a}$ is the inner surface of the equipment where the specimen is attached to be tested in $\mathrm{cm}^{2}$, $\mathrm{A}$ is the cross-section area of the sample in $\mathrm{cm}^{2}, \mathrm{~L}$ is the thickness of the specimen in $\mathrm{cm}$, $\mathrm{t}$ is the period of time required to achieve $\mathrm{h}_{1}$ (initial height of the water column in $\mathrm{cm}$ equivalent to $2 \mathrm{~L}$ of water poured on the specimens and measured on the volume scale fixed at the basis of the system) and $h_{2}$ is the final height of the water column in $\mathrm{cm}$.

Li et al. [17] proposed a three-dimensional FE (3D) algorithm to investigate water transport in concrete saturated with heterogeneous mesostructure consisting of coarse aggregates, mortar matrix and interfacial transition zone (ITZ). The experimental and numerical study on water permeability of the concrete was carried out and the proposed algorithm was able to model the permeable characteristics of the concrete showing that the effective permeability coefficient of the concrete varied linearly with the volumetric fraction of aggregate, and nonlinearly when aggregate volumetric fraction of 0.4-0.5 is incorporated, due to the fact that more ITZ with relatively higher permeability is created in concrete. According to ACI 522R [3], the pervious concrete hydraulic conductivity minimum value is $1.40 \times 10^{-3} \mathrm{~m}_{\mathrm{s}} \mathrm{s}^{-1}$, while for conventional concrete this value is $10^{-12} \mathrm{~m} \cdot \mathrm{s}^{-1}$. Aiming at estimating the hydraulic conductivity of the pervious concretes of this study, a water permeability measurement system was developed by employing variable load since the proposed system measures the period during which a fixed volume of water percolates through a sample.

This study aims at validating measurements of water permeability coefficient in pervious concretes in a practical way and without the need of devices which require complex instrumentation. It is proposed a system that allows measurements to be performed by experimenting with characteristic variations of the dry and saturated water sample, in order to compare the results with literature data from other measurement systems. The proposal is to determine the influence of this variable in the measurement of water permeability in permeable concrete by a simple and practical system. Aiming at validating the study by comparing the obtained results with the literature, an experimental matrix was proposed considering three different pervious concretes obtained from aggregates of different granulometric size. The results for properties of void contents, mechanical properties of compressive strength, splitting tensile strength and modulus of elasticity of the experimental matrix make it possible to evaluate the development of pervious concretes and therefore, the measurement viability of the water permeability coefficient measurement for the proposed system.

\section{MATERIALS AND METHODS}

Materials: an experimental matrix was proposed considering three different pervious concretes obtained from aggregates of different granulometric size in order to make possible measurements of properties in the system proposed in the present study, as well as the variations of dry 
Table I - Physical and chemical properties of Portland cement CPIV-Votoran-32 and physical properties of the concrete aggregates.

[Tabela I - Propriedades físicas e químicas do cimento Portland CPIV-Votoran-32 e propriedades físicas dos agregados do concreto.]

\begin{tabular}{cccc}
\hline \multicolumn{2}{c}{ Cement } & Natural sand & Gravel of basaltic origin \\
\hline $\mathrm{CO}_{2}: \leq 30$ & Compressive strength: & & Specify gravity: $2.58 \mathrm{~g} . \mathrm{cm}^{-3}$ \\
$\mathrm{SO}_{3}: 1.7$ & 3 days: $17.9 \mathrm{MPa}$ & Specify gravity: & \\
Insoluble residue: 31.04 & 7 days: $22.9 \mathrm{MPa}$ & $1.54 \mathrm{~g} . \mathrm{cm}^{-3}$ & Water absorption: $3.05 \%$ \\
Specify gravity: $2.94 \mathrm{~g} . \mathrm{cm}^{-3}$ & 28 days: $35.6 \mathrm{MPa}$ & & \\
\hline
\end{tabular}

and saturated sample. In order to execute this experimental matrix, a pozzolanic Portland cement classed in accordance with the ASTM C595 [18] and EN 197-01 [19] standards was employed. Portland cement CPIV (Votoran-32) was characterized by density, compressive strength after 3, 7 and 28 days and chemical characterization. For obtaining the control concrete (CC) a natural quartz sand was used as fine aggregate while as coarse aggregates two gravels (A and B) of basaltic origin were employed. Both natural sand aggregate and basaltic gravel aggregate were characterized by specific weight in accordance with the ASTM C127 method [20], and water absorption was evaluated for basaltic gravel in accordance with the ASTM C127 method [20]. Table I shows the physical and chemical properties of Portland cement CPIV-Votoran-32 and the physical properties of the concrete and aggregates of this study. The granulometric size distribution of the natural sand and basaltic gravel are listed in Table II.

The coarse aggregate and the basaltic gravel were employed for the composition of the three other concretes, two concretes being designed by PC- 1 and PC- 2 with the granulometric size distribution made up of four aggregate diameters and one concrete of uniform dimension aggregate designed by PC-3 (Table III). For PC-1, PC-2 and PC-3 concretes natural sand was not used in opposition to the control concrete (CC). Concretes were dosed in mixes of 1:4 ratio (cement:aggregates) by volume. Based on these formulations and on the features defined for the composition of the CC, PC-1, PC-2 and PC-3 concretes the ingredients' amounts in $\mathrm{kg} . \mathrm{m}^{-3}$ were established (Table IV). The slump test (ACI 2113R-02) for pervious concrete is zero and, therefore, this test was not performed in this study [21].

Methods: the test was carried out under two conditions: under the dry sample in an oven for $24 \mathrm{~h}$ at $105^{\circ} \mathrm{C}$; and under the water saturated condition. Preparation and characterization of concrete: the molding of the samples was performed in cylindrical metal molds with dimensions of $100 \times 200 \mathrm{~mm}$ (diameter $\mathrm{x}$ height) and in prismatic metal molds with dimensions of $75 \times 75 \times 285 \mathrm{~mm}$ (height $\mathrm{x}$ width $\mathrm{x}$ length) in triplicate, for the different compositions (CC, PC-1, PC-2 and PC-3) in accordance with the Brazilian standard NBR5738 [22]. The concrete samples were kept in the molds for $24 \mathrm{~h}$ then they were demolded and cured in water for 7 and 28 days, to perform mechanical testing. For each formulation three concrete samples (plates)
Table II - Granulometric size distribution of the natural sand and gravel aggregates (basaltic origin).

[Tabela II - Distribuição granulométrica dos agregados naturais de areia e cascalho (origem basáltica).]

\begin{tabular}{|c|c|c|c|c|c|c|}
\hline \multirow{2}{*}{$\begin{array}{l}\text { Size } \\
(\mathrm{mm})\end{array}$} & \multirow{2}{*}{\multicolumn{2}{|c|}{$\begin{array}{c}\text { Natural sand } \\
(\%)\end{array}$}} & \multirow{2}{*}{\multicolumn{2}{|c|}{$\begin{array}{l}\text { Gravel A } \\
\quad(\%) \\
\text { Ret. }\end{array}$}} & \multicolumn{2}{|c|}{$\begin{array}{c}\text { Gravel B } \\
(\%)\end{array}$} \\
\hline & & Acc. & & & Ret. & Acc \\
\hline 19.0 & 0 & 0 & 0 & 0 & 1 & 1 \\
\hline 12.5 & 0 & 0 & 0 & 0 & 62 & 63 \\
\hline 9.5 & 0 & 0 & 0 & 0 & 27 & 90 \\
\hline 6.3 & 0 & 0 & 30 & 30 & 10 & 100 \\
\hline 4.75 & 0 & 0 & 40 & 70 & 0 & 100 \\
\hline 2.4 & 1 & 1 & 30 & 100 & 0 & 100 \\
\hline 1.2 & 3 & 4 & 0 & 100 & 0 & 100 \\
\hline 0.6 & 17 & 21 & 0 & 100 & 0 & 100 \\
\hline 0.3 & 40 & 61 & 0 & 100 & 0 & 100 \\
\hline 0.15 & 26 & 87 & 0 & 100 & 0 & 100 \\
\hline Bottom & 13 & 100 & 0 & 100 & 0 & 100 \\
\hline $\begin{array}{l}\text { Maximum } \\
\text { dimension }\end{array}$ & \multicolumn{2}{|c|}{6.3} & \multicolumn{2}{|c|}{12.5} & \multicolumn{2}{|c|}{25} \\
\hline $\begin{array}{l}\text { Fineness } \\
\text { modulus }\end{array}$ & \multicolumn{2}{|c|}{1.74} & \multicolumn{2}{|c|}{5.64} & \multicolumn{2}{|c|}{6.91} \\
\hline
\end{tabular}

Table III - Granulometric size distribution of the pervious concretes.

[Tabela III - Distribuição granulométrica dos concretos permeáveis.]

\begin{tabular}{|c|c|c|c|c|c|c|}
\hline \multirow{2}{*}{ Size $(\mathrm{mm})$} & \multicolumn{2}{|c|}{ PC-1 (\%) } & \multicolumn{2}{|c|}{ PC-2 (\%) } & \multicolumn{2}{|c|}{ PC-3 (\%) } \\
\hline & Ret. & Acc. & Ret. & Acc. & Ret. & \\
\hline 19.0 & $\overline{0}$ & $\overline{0}$ & $\overline{0}$ & 0 & $\overline{0}$ & 0 \\
\hline 12.5 & 25 & 25 & 0 & 0 & 0 & 0 \\
\hline 9.5 & 25 & 50 & 25 & 25 & 0 & 0 \\
\hline 6.3 & 25 & 75 & 25 & 50 & 100 & 100 \\
\hline 4.75 & 25 & 100 & 25 & 75 & 0 & 100 \\
\hline 2.4 & 0 & 100 & 25 & 100 & 0 & 100 \\
\hline 1.2 & 0 & 100 & 0 & 100 & 0 & 100 \\
\hline $\begin{array}{l}\text { Maximum } \\
\text { dimension }\end{array}$ & & & & 2.5 & & 5 \\
\hline $\begin{array}{l}\text { Fineness } \\
\text { modulus }\end{array}$ & & & & 0 & & 0 \\
\hline
\end{tabular}


Table IV - Mix of the concretes constituents in kg. $\mathrm{m}^{-3}$. [Tabela IV - Mistura dos constituintes dos concretos em $\left.k g . m^{-3}.\right]$

\begin{tabular}{ccccc}
\hline Mix & Cement & $\begin{array}{c}\text { Gravel - } \\
\text { basaltic }\end{array}$ & $\begin{array}{c}\text { Gravel - } \\
\text { natural sand }\end{array}$ & Water \\
\hline CC & 418.00 & 1024.10 & 648.00 & 205.0 \\
PC-1 & 321.12 & 1284.48 & - & 112.4 \\
PC-2 & 310.28 & 1241.12 & - & 108.6 \\
PC-3 & 295.32 & 1181.30 & - & 103.4 \\
\hline
\end{tabular}

were molded, having dimensions of $200 \times 200 \times 30 \mathrm{~mm}$ (length $\mathrm{x}$ width $\mathrm{x}$ height) for executing the permeability experiments exhibiting the different compositions of the pervious concretes. The concrete test specimens of the pervious concrete mixes (CC, PC-1, PC-2 and PC-3) were characterized by bulk density in accordance with the ASTM C1754 method [23]. The void contents were calculated in accordance with ASTM C1754 [23]. Splitting tensile strength and compressive strength (Emic, PC-200I) were determined in accordance with the ASTM C496 [24] and ASTM C39 [25] methods, respectively. The test specimens' modulus of elasticity was obtained in accordance with the Brazilian standard NBR8522 [26] and ASTM C469 method [27] (strain-gauge EE08). All the experiments were performed in triplicate.

Equipment specification and assessment of the permeability coefficient: the system for measuring water permeability proposed in this study is illustrated in Fig. 1. The proposed measurement system for monitoring the water permeability was constructed in glass; it had dimensions of $222.33 \mathrm{~mm}$ (outer side), $211.70 \mathrm{~mm}$ (inner side) and 300 $\mathrm{mm}$ (height, Fig. 2). Glass fillets were attached to the inner walls of the mechanism, at the height of $150 \mathrm{~mm}$, serving as a support for the sample to be tested (plate). The system had a volumetric ruler attached to its body that enabled the measurement of the water volume in the system. For the test $2 \mathrm{~L}$ water were employed, this being equivalent to a gauge of $59 \mathrm{~mm}$ at the volumetric scale $\left(\mathrm{h}_{1}\right)$ which was attached at the basis of the system (Fig. 2c). A cover at the basis of the equipment sealed the outflow of water. Before carrying out the test on the pervious concrete plate, the volume occupied at the volumetric scale attached at the basis was measured, such volume was equivalent to the $2 \mathrm{~L}$ of water permeated on the plate tested $\left(\mathrm{h}_{1}\right.$ - value obtained from $59 \mathrm{~mm}$, which was equivalent to $2 \mathrm{~L}$ of water employed in the test).

Pervious concrete plates (samples) having dimensions of $200 \times 200 \times 30 \mathrm{~mm}$ (length $\times$ width $\times$ height) were attached to the system. The side of the plate (sample) was sealed to prevent preferential water paths. $2 \mathrm{~L}$ of water to be poured on the sample were stored in two natural rubber balloons. The water storage devices were opened and released the water instantly on the entire sample, homogeneously. This time was set as the beginning of the measurement time (t) of water flow between the starting point $\left(h_{1}\right)$ and the final point $\left(h_{2}\right)$, corresponding to the measured water after the test. It

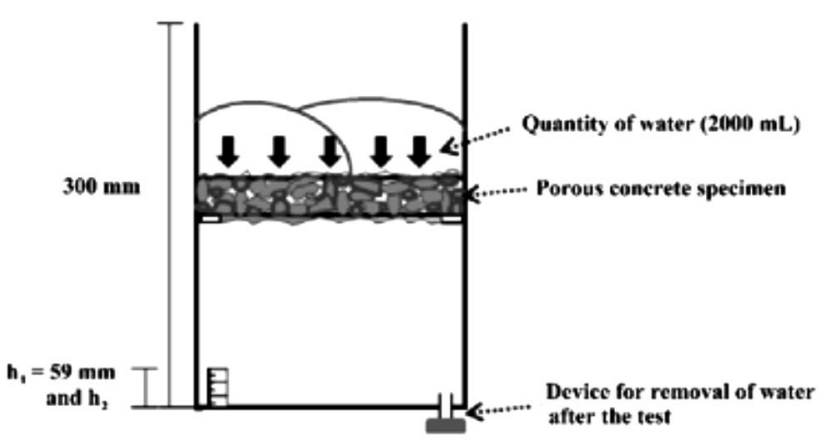

$h_{1}=$ initial volume of water $(2000 \mathrm{~mL}=59 \mathrm{~mm})$

$h_{2}=$ volume of water in $\mathrm{mL}$ after test measured with pachymeter

Figure 1: Schematic representation of the system for water permeability measurement of a pervious concrete plate.

[Figura 1: Representação esquemática do sistema de medição da permeabilidade da água em uma placa de concreto permeável.]
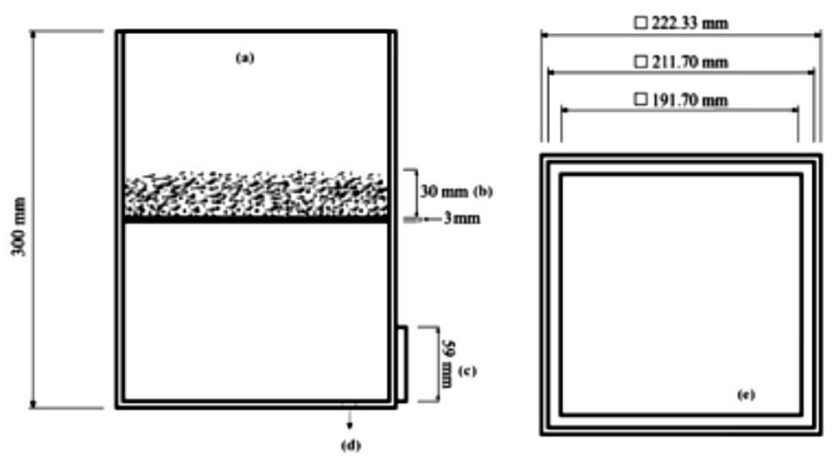

Figure 2: System design for water permeability measurement on a concrete plate where: (a) room for placing the water to be employed in the test, (b) concrete plate thickness, (c) device for volume measurement, which was equivalent to $2 \mathrm{~L}$ of water, (d) water outflow, and (e) top view of the system with its respective dimensions.

[Figura 2: Projeto do sistema para medição da permeabilidade da água em uma placa de concreto, onde: (a) espaço para colocar a água a ser utilizada no ensaio, (b) espessura da placa de concreto a ser testada, (c) dispositivo para medição de volume, (d) saída de água e (e) vista superior do sistema com as respectivas dimensões.]

was measured with the aid of a digital caliper. The prediction of permeability coefficient was calculated according to Eq. B. For validating the equipment, two different measurement conditions were proposed: the condition where the specimen is dried in an oven for $24 \mathrm{~h}$ at $105^{\circ} \mathrm{C}$ and the condition of specimen saturated in water, adapted from the ASTM C127 method [20]. Besides evaluating the concrete permeability under different conditions, a further aim was to check for the accuracy of the proposed measurement equipment.

\section{RESULTS AND DISCUSSION}

Characterization of pervious concrete: the density values of pervious concrete samples were between 1500 and $1629 \mathrm{~kg} . \mathrm{m}^{-3}$, being smaller than those for CC $\left(2820 \mathrm{~kg} \cdot \mathrm{m}^{-3}\right)$. The densities of the pervious concretes were within the recommended range by the literature for these materials $[6,7]$. The density 
of pervious concrete depends on the properties and the proportions of the materials used for its application [28] and this value is also attributed to the presence of voids [29], i.e. the lower the density of pervious concrete, the greater the void content. With respect to void content, the results are shown in Fig. 3. The values found for void contents in pervious concrete were $17 \%$ to $18.2 \%$, within the recommended range for this type of concrete [30]. The water permeability and void content of cementitious materials is influenced by many factors, for example, the experimental conditions such as sample size and shape or interaction between binders, water, and aggregates. The reduction or increase of the final void content and permeability for conventional concretes is mainly due to the continuous hydration of the cement, water/ cement ratio, as well as the characteristics of the porous network of the cement-based material [31]. In the case of pervious concretes, the main reason for the increase of void content is the porous structure made by the particle sizes of the aggregates. The control concrete $\mathrm{CC}$ showed higher density due to its low void content (1.6\%). PC-1, PC-2 and PC-3 showed void content values higher than the CC. The replacement of sand for larger particles (2.4 to $12.5 \mathrm{~mm}$ ) disrupted the granular concrete arrangement [15], increasing the amount of voids. The highest void content value was obtained for the PC-1 concrete, with particle sizes ranging from 4.8 to $12.5 \mathrm{~mm}$.

Test results of compressive strength for pervious concrete are shown in Fig. 4. For the CC an increase in compressive strength was observed from 26.0 to $37.7 \mathrm{MPa}$ from 7 to 28 days since this kind of concrete is constituted by coarse and fine aggregates. The pervious concrete PC-1 with particle size ranging from 4.8 to $12.5 \mathrm{~mm}$ presented the lowest compressive strength of $11.5 \mathrm{MPa}$ at 7 days and 21.1 $\mathrm{MPa}$ at 28 days. For the PC-2 and PC-3 pervious concretes it could be observed that the compressive strength increased from $19.3 \%$ to $22.3 \%$ after 28 days, as compared with the pervious concrete PC-1 which was $9.6 \%$ (after 28 days). All of the pervious concretes had compressive strength values lower than those of conventional concrete, which increased

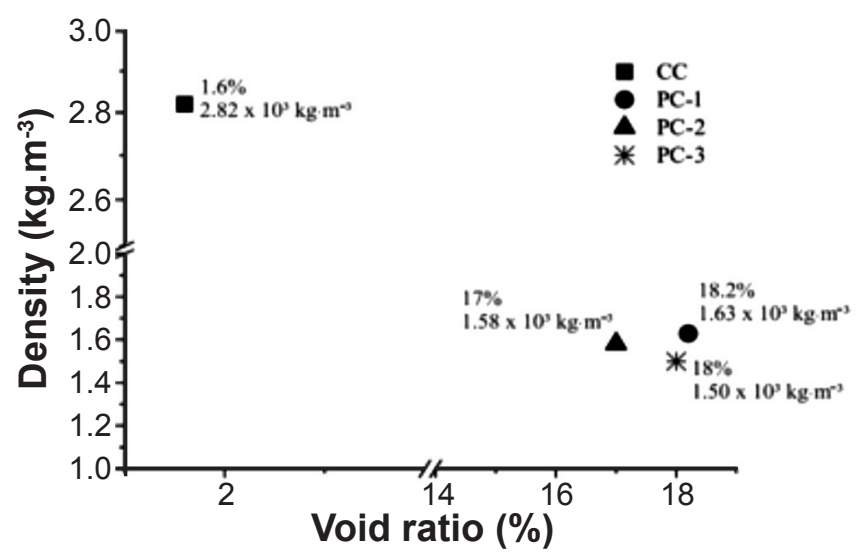

Figure 3: Density and void content of the pervious concrete proportions.

[Figura 3: Densidade e índice de vazios do controle e das proporções de concretos permeáveis.] by $31.1 \%$ after the 28 days test. The low compressive strength of the concretes PC1, PC2 and PC 3 can be attributed to the discontinuous matrix of the material (function of the particle size of the aggregates) which, in order to guarantee the voids that make the concrete permeable, weaken the whole. The concretes of this study (PC-1, PC-2 and PC3 ) had higher void contents when compared with $\mathrm{CC}$ and consequently lower compressive strength. Fracture occurred in the void near the paste/aggregate interface area due to smaller quantities of this material, which surrounds the gravel grains in the pervious concrete case. This behavior suggested that this zone is the weakest point of binding in pervious concrete. The pervious concrete consists of cement (cement and water), aggregate (gravel) and the transition zone between them. The transition zone influences the mechanical behavior of pervious concrete significantly and is considered the weakest link in concrete [29]. The strength of concrete is actually determined by the properties of the cement paste in the case of pervious concrete, and mortar for conventional concrete, coarse aggregate and the transition zone between them [32].

The splitting tensile strength test was performed at 28 days of age and the results are shown in Fig. 5a and the modulus of elasticity at 28 days of age is displayed in Fig $5 \mathrm{~b}$. These tests were not executed in triplicate. The splitting tensile strength of the pervious concrete ranged from 1.51 to $2.20 \mathrm{MPa}$. The splitting tensile strength was higher for the PC-1 pervious concrete with particle sizes ranging from 4.8 to $12.5 \mathrm{~mm}$. The splitting tensile strength generally ranges between $150 \mathrm{psi}(1 \mathrm{MPa})$ and $550 \mathrm{psi}(3.8 \mathrm{MPa})$ for pervious concretes. Thus, all pervious concrete studied presented values within the indicated literature [4]. Again, the particle size structure of aggregates required to ensure the permeability of the pervious concrete was responsible for the low values of mechanical tensile strength, as was the case with the compressive strength. The modulus of elasticity of the pervious concretes varied from 13.8 to 15.5 $\mathrm{GPa}$. The modulus of elasticity was greater for the pervious concrete PC-3 of uniform aggregate dimension of $6.3 \mathrm{~mm}$.

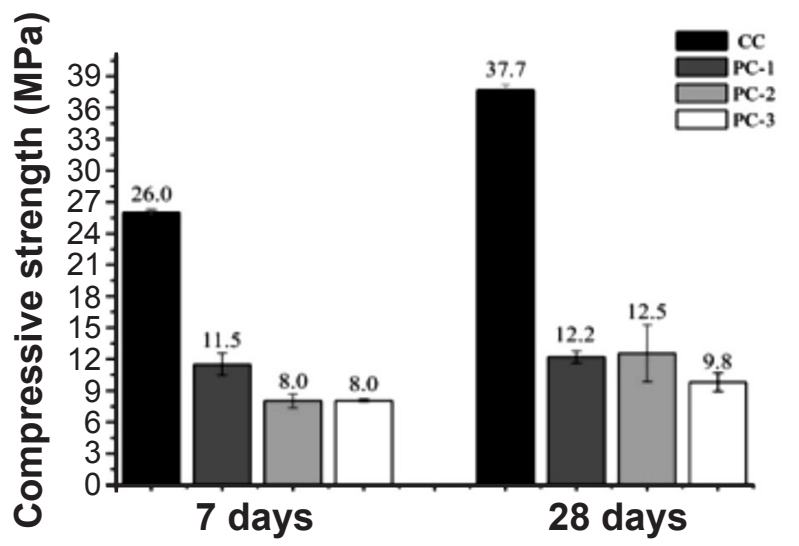

Figure 4: Compressive strength for the test specimens of the $\mathrm{CC}$, PC-1, PC-2 and PC-3 concretes, after 7 and 28 days of age.

[Figura 4: Resistência à compressão para as amostras dos concretos CC, PC-1, PC-2 e PC-3, após 7 e 28 dias de idade.] 

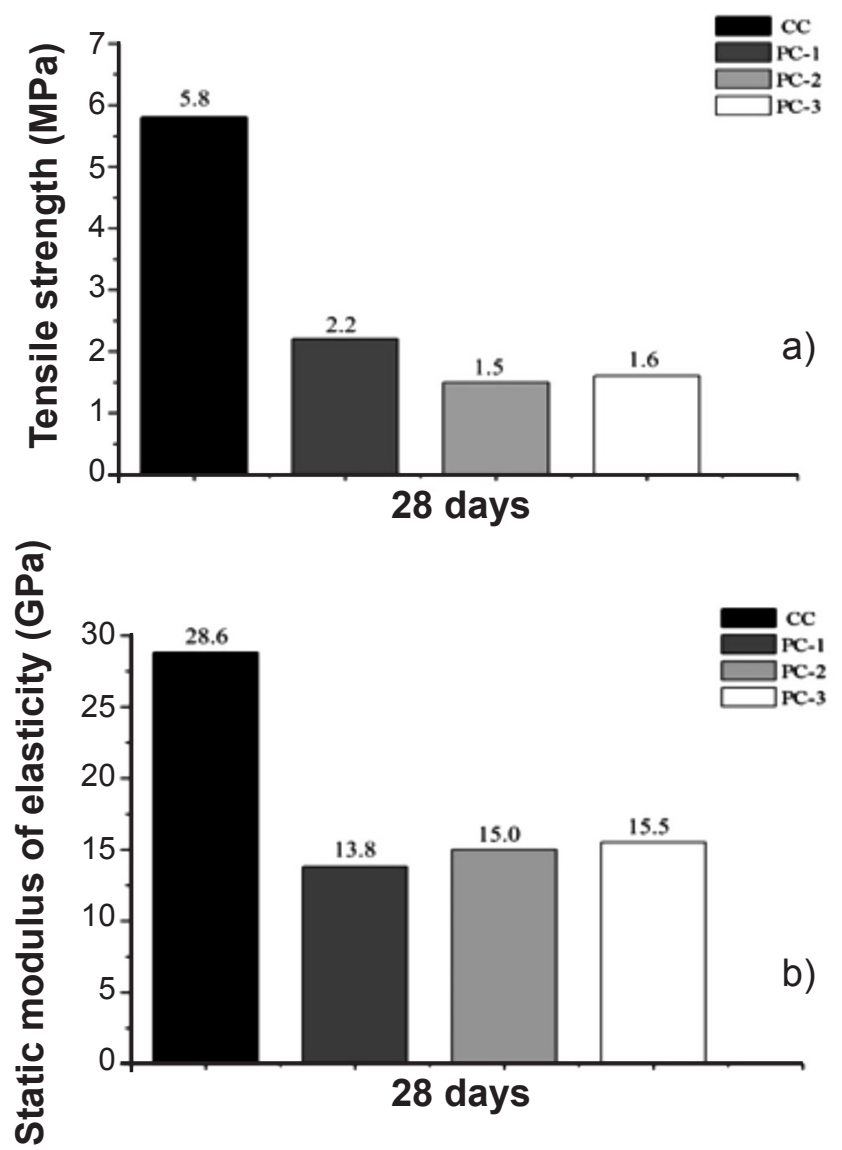

Figure 5: Splitting tensile strength (a) and modulus of elasticity (b) for the CC, PC-1, PC-2 and PC-3 concretes test specimens after 28 days of age.

[Figura 5: Resistência à ruptura (a) e módulo de elasticidade (b) para as amostras de concreto CC, PC-1, PC-2 e PC-3 após 28 dias de idade.]

The highest modulus of elasticity value of $15.5 \mathrm{GPa}$ for the PC-3 specimen can be attributed to the uniform aggregate dimension, which promoted the occurrence of a betterinterconnected pore network, entailing a reduction in failure propagation and increasing the energy absorption ability [33].

Water permeability and permeability coefficient: the results for the permeability coefficient (k) determined by Darcy's law (Eq. B) under the condition of dry sample in an oven for $24 \mathrm{~h}$ at $105^{\circ} \mathrm{C}$ and under the condition of watersaturated sample for three proportions of pervious concrete are shown in Fig. 6. The permeability coefficients of the specimens varied from 0.16 to $0.2 \mathrm{~cm} \cdot \mathrm{s}^{-1}$ with the exception of the CC [3] sample. For the PC-1 sample increase in permeability coefficient from 0.11 to $0.16 \mathrm{~cm} . \mathrm{s}^{-1}$ was observed under the dry condition to the saturated one, justified by the presence of larger particle size ( 4.8 to $12.5 \mathrm{~mm}$ ). No changes were observed in the permeability coefficient from the dry condition to the saturated sample condition for the PC-2 and PC-3 concrete mixes. The water-saturated sample conditions did not influence the increase in the samples' permeability coefficient since they consisted of similar water absorption

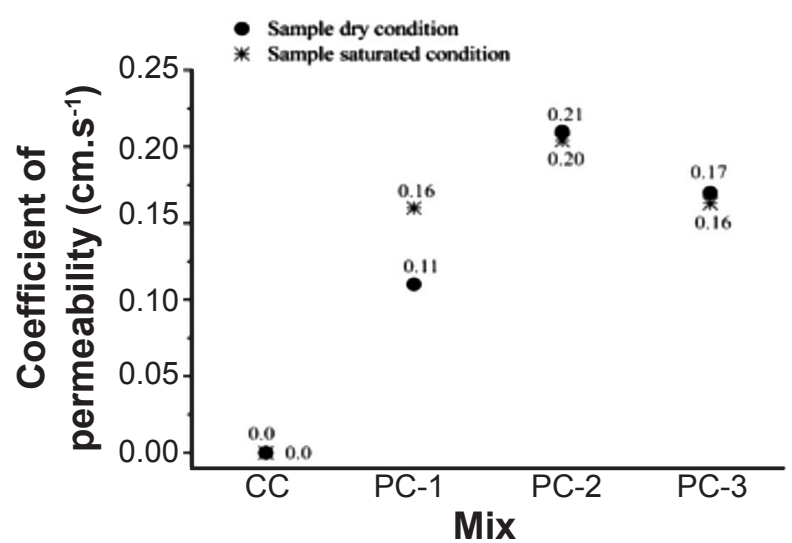

Figure 6: Permeability coefficient of the concrete proportions under the conditions dried specimen $\left(24 \mathrm{~h}\right.$ at $\left.105^{\circ} \mathrm{C}\right)$ and saturated specimen $\left(24 \mathrm{~h}\right.$ at $\left.23^{\circ} \mathrm{C}\right)$.

[Figura 6: Coeficiente de permeabilidade das proporções de concreto sob as condições amostra seca $\left(24\right.$ h a $\left.105^{\circ} \mathrm{C}\right)$ e amostra saturada $\left(24\right.$ ha $\left.23^{\circ} \mathrm{C}\right)$.]

materials. Results obtained with the system proposed in this work for the measurement of the permeability coefficient by employing the variable load method (Fig. 6) and calculated from Eq. B were similar to the results for the coefficient measurement obtained by using the variable load method proposed by ACI 522R [3], both being results obtained within the range predicted by the literature, validating the permeameter proposed in this study.

\section{CONCLUSIONS}

The system proposed for the measurement of the permeability coefficient by employing the variable load method for all of the pervious concretes (PC-1, PC-2 and PC3 ) enabled the assessment of results within ranges predicted in the literature, which validated the permeameter proposed in this study. The water saturated sample conditions did not influence the increase in the samples' permeability coefficient since they consisted of similar water absorption materials. The coefficient of permeability of PC-1 pervious concrete (particle sizes ranging from 4.8 to $12.5 \mathrm{~mm}$ ) of $0.16 \mathrm{~cm} . \mathrm{s}^{-1}$ was smaller than the PC-2 pervious concrete (particle sizes ranging from 2.4 to $9.5 \mathrm{~mm}$ ) of $0.2 \mathrm{~cm} . \mathrm{s}^{-1}$. The use of particle sizes ranging from 4.8 to $12.5 \mathrm{~mm}$ in PC-1 pervious concrete generated a slightly more fragile structure, decreased the compressive strength (11.5 MPa) when compared with $\mathrm{PC}-2$ pervious concrete of smaller particle sizes (12.5 MPa). The results of tensile strength were within the range recommended in the literature between 1.51 and 2.20 MPa. The mechanical behavior of the permeable concretes, as expected, was highly influenced by the absence of fine aggregates, which, while generating conditions for the creation of a network of permeable pores, created discontinuities in the concrete matrix. This discontinuity of the matrix considerably reduced the mechanical resistance of the permeable concretes, constituting the greatest challenge of their viability. The properties of void content, compressive strength, splitting tensile strength and modulus of elasticity 
of the experimental matrix validated the production of pervious concretes and, therefore, validated the proposed measurement system.

\section{ACKNOWLEDGEMENT}

The authors are grateful to the staff of the Laboratory of Constructive Materials Technology (LBTEC) of the University of Caxias do Sul, RS, Brazil.

\section{REFERENCES}

[1] N. Neithalath, M.S. Sumanasooriya, O. Deo, Mater. Charact. 61 (2010) 802.

[2] V.R. Schaefer, J.T. Kevern, "Final report", Nat. Concr. Pavem. Techn. Center, USA (2011).

[3] ACI 522R-06, Am. Concr. Inst. Comm. (2006).

[4] L.K. Crouch, A. Sparkman, T.R. Dunn, R. Hewitt, W. Mittlesteadt, B. Byard, J. Pitt, in: Proc. Concr. Techn. Forum, Nat. Ready Mixed Concr. Ass., USA (2006).

[5] N. Neithalath, J. Weiss, J. Olek, Cem. Concr. Res. 36 (2006) 2074.

[6] Nat. Ready Mixed Concr. Ass., http://www. perviouspaviment.org (2010).

[7] P.D. Tennis, M.L.Leming, D.J.Akers, "Pervious concrete pavements", Portland Cem. Ass., Skokie (2004).

[8] D. Huffman, in: "The concrete specifier" (2005) 42.

[9] J. Olek, W.J. Weiss, N. Neithalath, A. Marolf, E. Sell, W.D. Thornton, "Development of quiet and durable porous Portland cement concrete paving materials", Final Rep. SQDH 2003-5, Purdue Un., USA (2003).

[10] M.S. Sumanasooriya, N. Neithalath, ACI Mater. J. 106 (2009) 429.

[11] F. Montes, L. Haselbach, Environ. Eng. Sci. 23 (2006) 960.

[12] H.T. Ghashghaei, A. Hassani, Mater. Sci. Appl. 7 (2016)
101.

[13] M.A.R. Bhutta, N. Hasanah, N. Farhayu, M.W. Hussin, M.B.M. Tahir, J. Mirza, Constr. Build. Mater. 47 (2013) 1243.

[14] Y. Zaetang, A. Wongsa, V. Sata, P. Chindaprasirt, Constr. Build. Mater. 48 (2013) 585.

[15] D.H. Nguyen, M. Boutouil, N. Sebaibi, L. Leleyter, F. Baraud, Constr. Build. Mater. 49 (2013) 151.

[16] C. Lian, Y. Zhuge, Constr. Build. Mater. 24 (2010) 2664

[17] X. Li, Q. Xu, S. Chen, Constr. Build. Mater. 105 (2016) 503.

[18] Am. Soc. Test. Mater., C 595 (2008).

[19] Eur. Comm. Stand., EN197-1 (2002).

[20] Am. Soc. Test. Mater., C127 (2001).

[21] ACI 211.3R-2, "Guide for selecting proportions for noslump concrete" (2002).

[22] Ass. Bras. Norm. Técn., NBR 5738 (2008).

[23] Am. Soc. Test. Mater., C1754 (2012).

[24] Am. Soc. Test. Mater., C496 (1996).

[25] Am. Soc. Test. Mater., C39/C39M (2003).

[26] Ass. Bras. Norm. Técn., NBR 8522 (2003).

[27] Am. Soc. Test. Mater., C469 (2004).

[28] V. Sata, A. Wongsa, P. Chindaprasirt, Constr. Build. Mater. 42 (2013) 33.

[29] A. Zouaghi, T. Nakazawa, F. Imai, N. Shinnishi, Trans. Jpn. Concr. Inst. 20 (1998) 31.

[30] B. Huang, H. Wu, X. Shu, E.G. Burdette, Constr. Build. Mater. 24 (2010) 818.

[31] A. Amriu, M. Bencheikh, Constr. Build. Mater. 151 (2017) 642.

[32] M. Vancura, K. Macdonald, L. Khazanovich, Cem. Concr. Compos. 33 (2011) 1080.

[33] O. Deo, N. Neithalath, Constr. Build. Mater. 25 (2011) 4181.

(Rec.05/02/2017, Rev.08/07/2017, 15/02/2018, 09/04/2018, Ac. 18/04/2018) 